\title{
Changes in the Foreign Policy of Bolivia and Ecuador: Domestic and International Conditions
}

\author{
André Luiz Coelho Farias de Souza ${ }^{1}$ \\ https://orcid.org/0000-0002-1632-0098 \\ Clayton M. Cunha Filho ${ }^{2}$ \\ https://orcid.org/0000-0001-6073-3570 \\ Vinicius Santos ${ }^{3}$ \\ https://orcid.org/0000-0003-0907-7832
}
1Universidade Federal do Estado do Rio de Janeiro, Department of Political Studies, Rio de Janeiro/RJ, Brazil
${ }^{2}$ Universidade Federal do Ceará, Department of Social Sciences, Fortaleza/CE, Brazil 3Universidade Federal de Minas Gerais, Belo Horizonte/MG, Brazil

\begin{abstract}
The aim of this paper is to assess the changes in the foreign policy of Bolivia and Ecuador during the administrations of Evo Morales (20062019) and Rafael Correa (2007-2017), taking into account the interaction between domestic and international factors in both countries. Our working hypothesis argues that the reorientation of the foreign policy of these countries was possible due to a connection between alterations observed in the domestic and international spheres starting in the middle of the 2000s. In the internal sphere, the greater political stability resulting from the restructuring of the party system; in the foreign policy environment, an international system more open to the progressive field, allowing a change in the orientation of Bolivian and Ecuadorian foreign policy, based on that moment on the diversification of partnerships with an anti-United States bias.
\end{abstract}

Keywords: Ecuador; Bolivia, Foreign Policy; Evo Morales; Rafael Correa.

http://doi.org/ 10.1590/1981-3821202000030004

For data replication, see: https://doi.org/10.7910/DVN/T8YQH1

Correspondence: André Luiz Coelho Farias de Souza. E-mail: andreluizrj@gmail.com

This publication is registered under a CC-BY Licence. 
$\mathrm{T}$ he beginning of the twenty-first century was marked by a period of reordering in the international scenario. While initially the post-Cold War period was characterized by the idea of a unipolar world centered on the role of the United States and the expansion of liberal institutions and values in the political, economic, and social environment, the new millennium has distinct characteristics. In fact, the most recent period is based on the ascension of the so-called 'emergent powers', the decentralization of power, and the emergence of 'new' themes in the agenda among states (social justice, the fight against poverty, the recognition of minorities, etc), as well as the emphasis on US foreign policy in the War against Terror and the consequent loss of relevance of Latin America to the power in the North.

This new design of the international scenario has been shown to be crucial to Latin American countries, whose agri-exporting economies were boosted by rising international demand, especially Chinese, for natural resources and the increase in the value of commodities in the financial market. In the case of South American countries (with a broad concentration of natural resources), the changes mentioned configured a field favorable to the emergence and consolidation of governments considered to be leftwing or center-left, which included in their agenda the pursuit of more autonomous policies.

The phenomenon of the ascension of these governments has been given different names, such as the 'pink wave', 'progressive administrations', 'a swing to the left', 'social democracy in South America', as well as typological divisions represented by 'populism and social democracy', 'left renovators', and 'refounders' (LIMA, 2008; PANIZZA, 2006; SILVA, 2014) In common, these formulations point to the implementation of projects critical of neoliberalism, the promotion of social policies, and the inclusion of popular demands, historically relegated to the margins. In Ecuador and Bolivia, these projects also sought the nationalization of their economies and the 'refoundation of the state', with the enacting of new constitutions and the renovation of national political elites after a period of intense mobilization of civil society and strong organization of indigenous groups. In both countries, changes in the domestic sphere were accompanied by a governmental administration which gave a new tone to foreign policy. 
Starting from the perspective of foreign policy as a game with two levels (PUTNAM, 1988), our working hypothesis argues that the reorientation of Bolivian and Ecuadorian foreign policy reflects a connection between the alterations observed in the domestic and international spheres from the 2000s onwards. The election of progressive presidents, who were successful in forming parties or coalitions which became hegemonic, linked to a more open international system, allowed a change in Ecuadorian and Bolivian foreign policy, based on the diversification of partnerships and an anti-US discourse.

The article is divided into three main sections, in addition to this introduction: the first is concerned with Bolivia and the second with Ecuador, emphasizing the presidencies of Morales and Correa. In both cases, we introduce the respective sections with a brief overview of the main political events of the last 25 years to afterwards discuss Ecuadorian and Bolivian foreign policy, highlighting the alterations in conditions which allowed changes in programmatic orientation. The analysis of the trajectory of the two countries appears to suggest that the connection between elements of the two levels in the period in question has generated the necessary conditions for greater autonomization and the stabilization of the foreign policy. Finally, we finish the article with a recapitulation of the argument and brief final considerations about the new reorientations of foreign policy after the departures of Morales and Correa from their respective governments, despite this not being the focus of our article.

\section{Bolivia in the last 25 years}

Since its independence Bolivia's history has been marked by countless uprisings, coups d'état, and civil wars. The 1952 Revolution, which favored agrarian reform, the nationalization of mines, and the establishment of universal suffrage, was replaced in 1964 by a series of coups and military dictatorships, frequently unstable and with contradictory orientations. This dragged out interspersed by occasional civilian governments - until the 1980s. After the return to democracy in 1982 and the turbulent and unstable first civilian government, in the five presidential elections held between 1985 and 2002 three parties took turns in power by forming coalition pacts in parliament which came to 
include an increasing number of partners among the smaller parties in the political system.

It should be highlighted that the Bolivian constitution at the time established that in the absence of an absolute majority for any candidate, the president was chosen by the elected legislature in an indirect second round among those most voted. Since in the period in question no candidates were elected directly in the first round, it became known as a 'Pacted Democracy' and was marked by a programmatic convergence related to market reforms and representative democracy, reaching a historically unprecedented presidential succession via elections five times in a row. However, stabilization came at the cost of the virtual shielding of the system against the inclusion of new demands and actors. Programmatic convergence in relation to neoliberal policies among all the significant parties created growing discontent with the model, to the extent that the reforms were not only incapable of resolving the country's serious socioeconomic problems, but were also perceived by the population as having aggravated them. Despite this, they were nonetheless invariably maintained, irrespective of the government or the party in power (CUNHA FILHO, 2017; KOHL and FARTHING, 2006).

In part as an attempt to alleviate some of the democratic deficits of the model and in part seeking to create support for the market reforms implemented concomitantly, during Gonzalo Sánchez de Lozada first term (1993-97) important constitutional and political reforms were carried out which recognized for the first time, albeit in an incipient manner, the country as multicultural and pluri-ethnic. More than three hundred municipal prefectures were created for the first time with a judicially guaranteed budget in the vast rural zones. A mixed election system was adopted for the Chamber of Deputies, where approximately half of the parliamentarians would be elected in party lists and the other half through uninominal districts.

Despite being perceived by the population as insufficient and having failed, these reforms had the unanticipated effect of opening an important window of opportunities for new political actors - above all from the Bolivian countryside resulting in the election of a new generation of mayors and deputies who served as 
the foundation for the shaping of 'anti-establishment' political instruments with a national scope (ALTMAN and LALANDER, 2003; CUNHA FILHO, 2018a, 2018b; MOLINA, 2001; HAARSTAD and ANDERSSON, 2009; KOHL and FARTHING, 2006). Sánchez de Lozada's second electoral victory in 2002, a mere two percentage points ahead of Evo Morales, running for the presidency for the first time with a new indigenous-peasant based party Movimiento Al Socialismo (MAS - Movement to Socialism), showed the nature of the ongoing transformations. Moreover, his term would mark the definitive collapse of the model, which despite having received much praise (for example, HOFMEISTER, 2004), had been demonstrating widespread signals of exhaustion (PACHANO, 2006).

Taking office in the middle of a serious fiscal crisis, Sánchez de Lozada faced severe upheavals in February 2003 when, after announcing both a wage freeze and an extraordinary tax on wages - IMF demands to reduce the budget deficit -, street protests developed into an open confrontation with the Police and the Army which left more than twenty dead. In October of the same year, the president resigned in the middle of the conflict known as the 'Gas War', when the announcement of plans to export Bolivian gas to the US through Chilean ports rekindled the memory of the loss of the country's coastline to its neighbor in the nineteenth century and served as the catalyst for the agglutination of a series of protests in a massive insurrection which would bury 'Pacted Democracy'. His vice-president, the historian and journalist Carlos Mesa, assumed the presidency seeking to find a balance between the demands for a national refoundation through a Constituent Assembly (CA) and the nationalization of the hydrocarbon sector and the fear of implementing this due to international pressure and from the local elites.

Mesa carried out a limited constitutional reform establishing consultation mechanisms such as plebiscites and referenda and held a plebiscite - with widespread electoral attendance - on alterations in the hydrocarbon sector, including a question about the possibility of the use of gas as a diplomatic weapon to recover the coastline. However, in his hesitations he was incapable of enacting the resulting Hydrocarbon Law or even actually convening the Constituent Assembly and resigned in the middle of strong protests in June 2005, opening the way for the anticipated elections at the end of the year, won for the first time in the first round by Evo Morales and MAS. 


\section{The Morales administration}

At the beginning of his administration Morales sought to meet the popular demands crystalized in the critical context of the Gas War through state intervention in and control of the gas industry - which guaranteed the government a substantial increase in revenue (KAUP, 2010; MIRANDA, 2008) - and by convening a Constituent Assembly for the first semester of 2006. However, the attempt to re-found the state and reverse the previous pro-market orientation triggered, at the same time, a strong reaction from the former political elites who had lost national power but who were entrenched in departmental governments, above all in the Northeastern region of the country, known as 'Media Luna' (Half Moon) and which concentrates the greatest part of agricultural and hydrocarbon production in the country.

In contrast to Ecuador, as will be discussed later in the article, the convocation of a Constituent Assembly did not imply the dissolution of the Legislature, with the existing Congress maintaining its functions all the time. Regional opposition groups demanding departmental autonomy acted in a disloyal manner, seeking to block the approval of governmental projects in the Senate where they jointly had a majority - and also in the Constituent Assembly, where although they were in a minority they prevented the government from obtaining the two-thirds majority required to approve articles.

The situation of conflict escalated to extra-institutional confrontations which paralyzed the country and prevented the government in power from having access to some areas at certain periods between 2007 and 2008. Indeed, it would only be resolved at the end of the latter year after the holding of revocatory referenda for departmental governments and the president in August and the escalation of the conflict in September, followed by agreements with a moderate fraction of the opposition in the Senate which allowed the partial modification of the constitutional project submitted by the Constituent Assembly and the calling of confirmatory referenda in February 2009 (CUNHA FILHO, 2008). These finally approved the new constitution. While the beginning of his first term raised fears of the repetition of a never-ending history of institutional instability (GUIMARÃES; DOMINGUES, and MANEIRO, 2009), in his second term Morales 
obtained a qualified majority in both legislative houses and was capable of governing in a stable manner, becoming in October 2015 the president who had held the position for the most consecutive days when he beat the previous record of Marshal Andrés de Santa Cruz y Calahumana (1829-39) (GISBERT, 2006).

\section{Bolivian foreign policy}

In the Bolivian case, foreign policy was marked by the dialectic between internal factors and opportunities for international insertion. In other words, the history of political instability and institutional fragility of the country had a significant impact on its international capacity for action (CUNHA FILHO and VIANA, 2010; MAIRA, 2007), which combined with the tendencies and events of the international scenario as the conditioning factors of its foreign policy.

During the 1980s and 1990s Bolivia was marked by the chronic need to attract foreign resources to pay for its own budget and, as a consequence, its foreign policy was aligned with the market reform agenda defended by international financial institutions (KOHL and FARTHING, 2009) and governments from the capitalist center, above all the US, with whom the country came to significantly align itself, also due to anti-drug policies, strongly linked to the imperatives issued by that country. In parallel, it maintained its traditional diplomatic orientation as the "country of contacts" (BRUSLÉ, 2015), through which it sought to convert its geopolitical position - perceived as central on the continent - into a search for benefits and opportunities for national development.

Similarly, the country sought to position itself as the connection between the distinct projects of South American regional integration, adding to its position as a founding member of the Andean Pact (which became CAN (Comunidad Andina de Naciones) in 1996) and an associate member of Mercosur since 1996. After the signing of the Treaty of La Paz the same year and the resulting construction of the Brazil-Bolivia Gas Pipeline (Gasbol), finalized in 1999, the export of natural gas to the markets of its neighbor gradually became one of the principal sources of foreign currency in the country (DELGADO and CUNHA FILHO, 2016).

Evo Morales' assumption of the presidency occurred in a new regional context associated with the rejection of the neoliberal project which contributed to the reorientation of Bolivian foreign policy and its international insertion (MAIRA, 
2007; ROCHLIN, 2007). In this context, the new Bolivian foreign agenda went through a reorientation, moving away from a preferential relationship with the United States. Similar to Ecuador, central to this new direction of foreign policy was an emphasis on south-south cooperation and the strengthening of regional integration projects. It would also be marked by a preferential approximation with other leftwing Latin American governments, above all Venezuela (BIRNS and SANCHEZ, 2011; BONILLA and PÁEZ, 2006; CUNHA FILHO and DELGADO, 2010; DELGADO and CUNHA FILHO, 2016; ROJAS, 2014). Moreover, the country would seek to diversify its diplomatic relations among non-traditional partners in Africa and Asia, in order to reduce its dependence and increase its margins of autonomy, associated with the expansion of its capacity for diplomatic projection and the strengthening of internal development projects (CUNHA FILHO, 2016; CUNHA FILHO and GONÇALVES, 2010; DELGADO and CUNHA FILHO, 2016).

Due to the adoption of a statist economic policy which involved the renegotiation of a series of previous privatization contracts, Bolivia faced important conflicts with the countries in which the companies that had been totally or partially nationalized were based (FUSER, 2014) and with international financial institutions (KOHL and FARTHING, 2009), as a result of which it left the International Center for the Settlement of Investment Disputes (ICSID), linked to the World Bank and seen as biased in favor of transnational companies (BAS VILIZZIO, 2015).

The country would also adopt rhetoric that gave greater value to its sovereignty, anchored on the institutional refoundation carried out in the name, amongst other things, of the revalorization of traditions and indigenous culture and cultural decolonization, using the fact that Morales was the first indigenous president from the country to project an ecologist image and the defense of indigenous peoples, which resulted in a notable increase of Bolivian soft power and an unprecedented international projection much beyond the concrete weight of the country in the international system (AGUIRRE and COOPER, 2010; CUNHA FILHO, 2016; ROJAS, 2014).

This affirmation of national sovereignty and respect for its cultural traditions would also justify an important redefinition of official policy in relation to coca leaf, notably the attempt for its international decriminalization within the UN 
system (CUNHA FILHO and DELGADO, 2010). With the rejection of the initiative to remove the prohibition of the 'in natura' leaf from the Single Convention on Narcotic Drugs, the country withdrew from the treaty in 2011 to request reentry with the exception of articles aimed at prohibiting the production of the leaf, which was approved in 2013 and celebrated in the country as an important diplomatic victory.

\section{Regional integration projects}

As in the Ecuadorian case, Bolivia also sought to become significantly closer to Venezuela and Cuba. In relation to the Caribbean island, of importance were both ideological and symbolic aspects associated with the weight of the Cuban Revolution in the imagination of the Latin American left in general and the fact that Cuba was linked with Bolivia through the death in its territory of the guerrilla leader Ernesto 'Che' Guevara, as well as the importance of traditional Cuban cooperation in education and health. In relation to Venezuela, as well as the political affinity with the Chávez government, the technical and financial support given to Bolivia was decisive - indeed in the first two years of Morales' administration it was crucial since Venezuela funded a series of projects and small construction works in the country. This alignment was translated into the country's enthusiastic adhesion to the Bolivarian Alternative for the Americas (Alba) in 2006 (PÉREZ FLORES; KFURI, 2011).

As well as Alba, the country sought to adhere to and deepen its participation in all the regional mechanisms available, with the only exception being the Pacific Alliance seen as a neoliberal mechanism (CUNHA FILHO, 2015; DELGADO and CUNHA FILHO, 2016). Despite the international alignment with Venezuela, the country remained in CAN and defended its importance even after Venezuelan left the bloc in 2006. It joined the Union of South American Nations (Unasur) in 2008 and the Community of Latin American and Caribbean States (CELAC) in 2012 and has been seeking to revitalize URUPABOL, a trilateral integration accord with Uruguay and Paraguay.

Moreover, in 2012 Bolivia asked to change its status in Mercosur from associate to full member, being accepted by the other countries in 2015 and is 
currently in the adhesion process ${ }^{1}$. It should be highlighted that this decision was made for political motives, such as positioning itself as a pivot between the two largest and oldest South American integration blocs, and for direct economic interests (COSTOYA, 2011; LECHÍN, 2015), since its status as an associate member and the composition of its export agenda (concentrated fundamentally on gas, governed by its own treaties), already gave it sufficient access to market blocs. Seeking to return and update the traditional diplomatic agenda and positioning itself as a 'country of contacts' on the continent, the country has been giving special emphasis to its potential to convert itself into a pivot of continental energetic integration (BRUSLÉ, 2015; CUNHA FILHO, 2015; FRANÇA, 2015), as well as the nodal points of Atlantic-Pacific road and rail routes.

However, integration with the neighbors has not been exempt from tensions. The state recuperation of the gas industry, which commenced in 2006, put Bolivia on a collision course with Brazil, the principal export market for the product which controlled the largest part of Bolivian production through Petrobras. The ideological and personal affinity between presidents Morales and Lula helped keep these tensions down to some extent, however, the belief that this guaranteed a tranquil and generous acceptance on the part of Brazil is, as Fuser (2014) states, to a great extent a myth: Brazilian diplomacy was one of the strong agents of pressure on President Carlos Mesa after the holding of the 2004 plebiscites in the sense of attenuating the scope of the new hydrocarbon law which, as mentioned, Mesa did not enact, resigning the presidency due to the social pressure.

Moreover, the overcoming of moments of greater tension in the nationalization process of Bolivian gas involved new pressure on the Morales administration which led to some withdrawals on the part of Bolivia and implied the freezing by Brazil of joint development projects in the petrochemical sector (FUSER, 2014, p. 251).

On the other hand, in relation to Chile, a historic rival since the loss of the coastline in the nineteenth century and with whom the country did not have full diplomatic relations, bilateral relations commenced in surprisingly positive manner.

${ }^{1}$ All that is missing is its ratification by the Brazilian legislature, having been approved by other countries in the bloc.

(2020) $14(3) \quad$ e0008-10/37 
At the invitation of the outgoing president Ricardo Lagos, Morales participated in the inauguration ceremony for the first term of Michelle Bachelet in 2006 and the same year both countries announced a set of bilateral targets which became known as the 13 Points Agenda, including themes such as physical and frontier integration, public policy cooperation, and discussions without any exclusion about contentious issues such as the recuperation of access to the Pacific by Bolivia and about the nature and exploitation of hydric resources of Silala (CUNHA FILHO and DELGADO, 2010).

To the contrary of what was expected from Morales nationalist discourse, which led analysts to expect an immediate beginning of tensions with its historic rival, the political climate between Chile and Bolivia remained extremely positive during Bachelet's term and the two countries even came close to signing a treaty resolving the issue of Silala.

In this proposal, a bilateral scientific commission was to be established to determine the origin and nature of the waters ${ }^{2}$, with Chile committing itself to pay for half of the hydric volume used while the studies were being carried out and, after they finished, the accord was to be reassessed based on their results. The proposal was accepted by both governments, but ended up not being ratified by Bolivia at the last minute due to radicalized protests in Potosí which demanded the inclusion in the treaty of a recognition by Chile that it should pay the supposed historical debt for the unpaid use of the waters since then (CUNHA FILHO, 2015).

With the transition in the Chilean government and the inauguration of the conservative Sebastián Piñera in 2010, however, bilateral relations began to cool and public demands by the Bolivian government that it was time to advance to the point on the agenda dealing with access to the Pacific began to increase. Due to the lack of visible advances concerning the question, Morales announced during the commemorations of the Day of the Sea on 23 March 2011 that he would present the Bolivian case to the International Court of Justice (ICJ) in the Hague. After that the bilateral relationship began a process of deterioration and conflicts, which persisted even after the return of Bachelet to the

\footnotetext{
${ }^{2}$ The origin of the dispute is due to Chile considering that Silala is an international river whose waters it has the right to use, while Bolivia alleges that it is a water source artificially channeled to the territory of its neighbor and used for more than a century without any financial compensation.
} 
Chilean presidency in 2014. In relation to the maritime demand, the professionalism and solidity with which the Bolivian government and diplomacy dealt with the question was noteworthy, despite the initial accusations - internal and external that Morales sought to use the nationalist cause only to attract internal support.

The country created a new specific agency, the Strategic Directorate of Maritime Recovery (Diremar), consisting of historians, geographers, jurists, diplomats, military officers, and high-ranking government officials and charged with drafting its demands and seeking to strengthen it as a question of state, beyond the mere interests of government, inviting in an effective manner all former Bolivian presidents and foreign ministers to support and assist Diremar, and contracting former president Mesa as international spokesperson for the demand, as well as appointing the former president of the Supreme Court and interim president Eduardo Rodríguez Veltzé (2005) as a legal agent in the Hague for its effective presentation in April 2013 (CUNHA FILHO, 2015, 2014).

At the same time, as a complement, Bolivia has been working to activate the diplomatic agreements it had with Peru to use the ports of Ilo and to expand infrastructure connecting the two countries, as well as resuming the accords made under the auspices of URUPABOL to revitalize the waterways of the River Plate basin and the use of Uruguayan Atlantic ports as a form of reducing its dependence on Chilean ports and pressuring its neighboring country, whose northern region depends significantly on Bolivian commercial flows, to negotiate.

Bolivian solidity in relation to the issue was even more notable given the surprising lack of this on the Chilean side, with frequent public criticism and mismatches between authorities in relation to the actions of the foreign ministry or of judicial agents in relation to it. Bolivia claimed that Chile had offered at its own initiative a series of negotiations during the twentieth century aimed at recovering sovereign access to the sea for Bolivia and argued before the ICJ that these unilateral offers constituted a judicial obligation of the state and thus determined the obligation for Chile to return to negotiations in good faith for this objective.

The initial Chilean strategy sought to question the competence of the court to arbitrate on this question and when the ICJ rejected this in 2015 it marked a 
partial victory that was much celebrated on the Bolivian side and an increase in bewilderment in Chile. However, the final decision frustrated Bolivian diplomacy by establishing in October 2018 that Chile did not possess this judicial obligation, although urging both countries to maintain dialogue in order to resolve the dispute.

A secondary product of the bilateral crisis provoked by the maritime demand was the presentation by Chile of a case against Bolivia over the water from the Silala River in 2016, in which Chile solicited the recognition of the international nature of the river's waters. The official line of Bolivian diplomacy about the Chilean demand was to welcome it and treat it as an opportunity for the definitive solution of the conflict, with ample optimism that the ICJ judgment - expected for 2020 would be favorable to it.

\section{Extra-regional relations}

Extra-regional relations were orientated to the diversification of partnerships, meeting objectives that were at the same time ideological and pragmatic: on the one hand, reducing political dependence and the automatic alignment of the country with the directives of Washington aimed at affirming its own sovereignty through the consolidation of a network of contacts to serve it as support against pressure and, on the other, to reduce its economic dependence on a few foreign markets and thus increase its autonomy and development opportunities (BIRNS and SANCHEZ, 2011; CUNHA FILHO, 2016; CUNHA FILHO and GONÇALVES, 2010; AGUSTÍN, 2016). As well as becoming close with certain Middle Eastern countries such as Iran and Libya, Bolivia sought cooperation agreements in various sectors with Russia and Belarus, attempted an ill-fated steel partnership with India ${ }^{3}$ and - like the rest of Latin America - has been receiving increased Chinese investment (VALLE and HOLMES, 2013).

Moreover, as well as the above mentioned freezing of bilateral development projects with Brazil, it also made partnerships with South Korea in

\footnotetext{
${ }^{3}$ In 2007, the country signed an agreement with the Indian company Jindal Steel \& Power for the exploration and industrialization of the huge Mutún iron ore deposits in the Department of Santa Cruz. Due to the successive delays and non-fulfillment of project targets, the Indian company left the country in 2012. The project was halted, restarting in 2018 after the approval of Chinese credit for this purpose.
} 
important ongoing industrial projects to establish a complete petrochemical industry in the country, with the production of plastics, fertilizers, and chemical derivatives of gas, until then only used or exported in a raw manner. Similarly, for the mining sector the country has also been resorting to Asian cooperation to fund its projects, with notable Japanese, Chinese, and Korean participation, for example, industrialization projects for lithium, and also seeking German and French support and funding (CUNHA FILHO, 2016; REVETTE, 2016; STRÖBELE-GREGOR, 2013; VALLE and HOLMES, 2013).

Another striking characteristic of the foreign policy of the Morales administration resides in the projection of the indigenous and environmental question in the international sphere. According to Querejazu Escobari (2015), these actions by Bolivia are related not only to the scope of the objectives of foreign policy, but are also an attempt to construct a new national identity. Actually, the official discourse presented a dual face: at times presenting the indigenous people as the subjects in a 'process of change', sometimes presenting them as actors for a transformation of modern western civilization (DELGADO, 2014).

The indigenous question and its association with environmentalism in the defense of 'pachamama' is presented as a crucial point for the projection of the country in the international scenario and of its government, centered on the figure of the 'first indigenous president' of Bolivia. As mentioned, this strategy has validated a notable increase in the international visibility of the country, much above its real international geopolitical or economic weight ${ }^{4}$ (AGUIRRE and COOPER, 2010; CUNHA FILHO, 2016; ROJAS, 2014).

As an operative complement of this notable 'soft power', the country has sought to act in the multilateral bodies and integration agreements that it is part of as a form of projecting and disseminating, via a proxy through the positioning of the institution or of its most powerful members, its interests and proposal to the international system. The request to become a full member of Mercosur and the country's policy towards the so-called BRICS, for example, appear

\footnotetext{
${ }^{4} \mathrm{As}$ in the Ecuadorian case, this international discourse has increasingly entered into an internal contradiction with the expansion imperatives of an economy strongly dependent on agriextractivism. Important fractions of the Bolivian indigenous movement, as well as urban ecologist groups previously supportive of the government are currently in opposition.
} 
to be fundamentally aimed at this objective (AGUSTÍN, 2016; COSTOYA, 2011; LECHÍN, 2015).

\section{Relations with the US}

The Bolivian policy of defending the coca leaf heightened tensions between Bolivia and the United States based on the increasingly greater autonomy with which the country came to administer its drug policy, in contrast with the strong previous alignment established after the enactment of the Coca and Controlled Substances Law in 1988, under US patronage. It is worth noting that in the moments of greater tension between Morales and the 'Media Luna' governors in 2008, the then US ambassador Philip Goldberg was expelled from the country under the accusation of conspiring with the opposition, an expulsion soon extended to the US Drug Enforcement Agency (DEA). The crisis resulted in the cancellation by George W. Bush's administration of the commercial benefits of the Andean Trade Protection and Drug Eradication Act (ATPDEA) to the country, although Bolivia continued to comply with the requirements for the reduction in the area where coca was grown, to the contrary of countries such as Peru, which despite not fulfilling these requirements had their benefits maintained.

As previously mentioned, Bolivia sought to remove the prohibition of the coca leaf from the UN Convention on Narcotic Drugs, and given the impossibility of this abandoned the convention, later returning with the exception of recognizing the legitimacy of its traditional internal uses in 2013. However, this did not signify the adoption of heterodox policies or any departure from the prohibitionist paradigms in relation to the fight against drugs in a general manner. In relation to cocaine or other narcotics, Bolivia maintained the traditional policies of combating them and also signed various funding and cooperation agreements in the sector with the European Union, Russia, and South American neighbors.

Contrary to some expectations, Obama's inauguration in the US did not bring any great alterations to bilateral relations, with the maintenance of Bolivia's exclusion from ATPDEA and the incapacity to advance towards the replacement of ambassadors. The countries even signed a framework agreement for the normalization of diplomatic relations in 2011, but the appointment of ambassadors 
remained pendent between the two parts ${ }^{5}$ and in May 2013 - two years after signing the agreement - Morales would expel the United States Agency for International Development (USAID) from the country, accused of acting with political purposes in its projects.

In July of the same year the two countries would again face strong tensions when the plane bringing President Morales back from a meeting of gas exporting countries in Russia had its entrance into air space denied by France and Portugal, causing an emergency landing in Vienna. Morales accused the European governments of having acted under US orders due to the suspicion that his plane could be carrying the former US intelligence agent Edward Snowden, exiled in Russia.

A final point of tension between the countries has been the US refusal to extradite the former Bolivian president Sánchez de Lozada for trial over his responsibility for deaths during the Gas War. Given the difficulties in processing him criminally, the families of the victims of 'Black October', with the support of the government, sued the former president and one of his principal ministers in a Florida court. The former president and his former minister Sánchez Berzaín were condemned to pay $\$ 10$ million in compensation to the families of the victims in April 2018 and although this did not imply imprisonment it represented an important symbolic victory by putting a former foreign president before a US jury for abuses committed abroad.

In relation to international trade, despite the non-renovation of ATPDEA for Bolivia in 2008, the US remained an important export destination, with the value of exports to it even reaching a peak in the period after the end of the agreement. As an export destination, China showed a slow but steady growth until 2018, the year it reached the same level as the US. However, it is as a source of imports that the importance of the Asian country most stands out, surpassing the US in 2011 and growing significantly and almost continuously since then.

\footnotetext{
${ }^{5}$ Only on 26 November 2019, after the fall of the Morales administration, would Bolivia appoint Ambassador Walter Serrate, receiving in January 2020 the US promise of the rapid appointment of an ambassador to Bolivia.
} 
Graph 01. Bolivian trade flows (1991-2018)

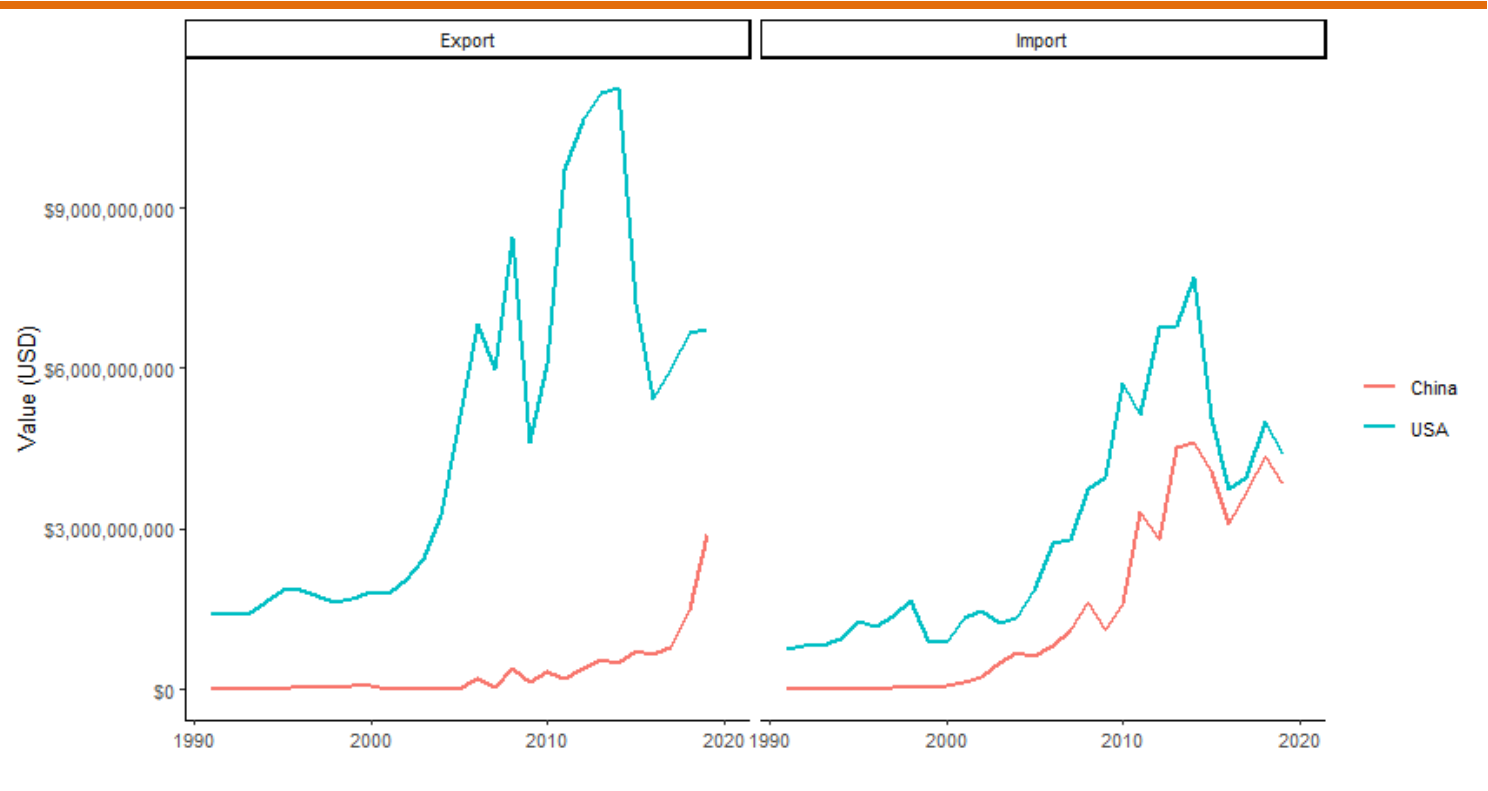

Source: Elaborated by the authors, based on UN Comtrade (2020).

\section{The history of recent instability of Ecuador}

When looking at the twentieth century in Ecuador, Souza (2007b) points to historical evidence of the concentrations of conflicts between the three powers which resulted in successive coup d'états and military dictatorships. This dynamic was dramatically illustrated in the twenty-three year period between 1925 and 1948 in which the country had 27 governments, of which twelve came to power due to the resignation or removal of the previous officeholder, eight formed dictatorships, four were elected by a Constituent Assembly (CA) and only three by direct suffrage. Although in the period immediately after this the country went through a certain stability with the succession of three democratically elected presidents between 1948 and 1961, Ecuador soon underwent a new moment of instability including new constitutions in 1963 and 1967, the indications of interim presidents, a presidential election followed by a so-called 'autogolpe' or self-coup in 1968 and a new military dictatorship between 1972 and 1979, the year of the return to democracy.

The return to democracy in Ecuador can be considered a landmark in the political scenario of the region, to the extent that it became the first country in South 
America to abandon an authoritarian regime after the wave of dictatorships that began in the 1960s and 1970s6.

With the end of the military dictatorship a very fragmented party system was established in Ecuador with a high degree of personalization. Indeed, until the arrival of Rafael Correa no party managed to elect a president for more than one term due to a situation of equilibrium and mutual veto power, which implied a high level of political instability. It was in this period that neoliberal political and economic reforms were implemented and which guided the actions of all presidents of the country before Correa (SOUZA, 2007b, p. 02).

Between 1979 and 2002, between nine and 19 parties were represented in parliament, with four of them electing representatives in only one of the eleven elections held, as well as a tendency towards what was called the 'provincialization of parties', with many of them obtaining a considerable localized vote, but one that was little dispersed nationally (PACHANO, 2008). However, despite the great electoral volatility, the fragmented political party seemed to progressively consolidate around four parties which concentrated $86.5 \%$ of seats in parliament in 1998 (PACHANO, 2008).

The recent moment of greater presidential instability began with the election of Abdalá Bucaram in 1996, who lasted only 186 days in office. According to Alberto Acosta (2006), Bucaram tried to push the Ecuadorian economy to a higher level of neoliberalism, looking for the rapid approval of a list of privatizations and labor reforms, as well as increases of $1000 \%$ in telephone tariffs, $300 \%$ in electricity tariffs, and 60\% in transport. Despite coming to power with a discourse critical of market reforms, he sought to deepen them in a manner not seen previously in the country (SOUZA, 2007a, p. 59), and was overthrown by a coup from the National Congress in 1997 under allegations of mental insanity. Even his vice-president, Rosalia Arteaga, only remained in power for a few days due to rejection of her by the members of congress. The president of Congress, Fabián Alarcón, assumed the presidency, remaining a year and a half in office.

\footnotetext{
${ }^{6}$ In this period, only two countries in the region did not have military dictatorships: Colombia and
} Venezuela. 
In 1998, Jamil Mahuad was elected president and managed to enact a new constitution for the country, after various attempts by previous governments. In this new constitution governability and the stability of the political system were its principal objectives, but in 2000 it would be the turn of Mahuad to be overthrown by the armed forces in the middle of protests by the Confederation of Indigenous Nationalities of Ecuador (CONAIE). According to Villa (2004): "The years between the triumph of Abdalá Bucaram (1996) and the fall of Jamil Mahuad in 2000 show the most complete institutional chaos of the contemporary institutional history of Ecuador" (VILLA, 2004, p. 141). During the 1990s, successive governments tried to carry out reforms to implement the adjustments agreed with the IMF. The most sensitive issues were privatizations, fiscal reforms seeking to expand the tax base, governmental attempts to reorganize state subsidies for agribusiness, and constitutional reforms to abolish communal property. In this set of measures, oil and its derivatives, as well as cooking gas, were always objects of taxation incursions by the Ecuadorian government to obtain credits from international agencies for financing. Ecuador's dependence on oil, the principal source of income for the country, made this area the center of the majority of strikes, shutdowns, and political crises (SOUZA, 2007a).

When Ecuador's level of indebtment and the need for the refinancing of the country is observed, the restricted degree of freedom which these administrations suffered and the consequences of this for the consolidation of political stability can be understood (SOUZA, 2007a). Between 1983 and 2000, Ecuador signed ten 'Letters of Intention' with the IMF and guaranteed the concession of eight new 'stand by' loans. For Alberto Acosta (2006), international financial institutions, notably the World Bank and the IMF, were the fundamental actors in this process, since the intersecting conditions were determinate for the establishment of Ecuadorian economic policies since redemocratization.

Acosta (2006, p. 170) also stated that without the approval of these institutions it was difficult for a country to receive foreign investment, as this approval had become a type of 'guarantee seal' for investors. Although it was not the main factor, the country's great economic dependence was reflected in the great volatility of ministers, chronic corruption, incapacity to form 


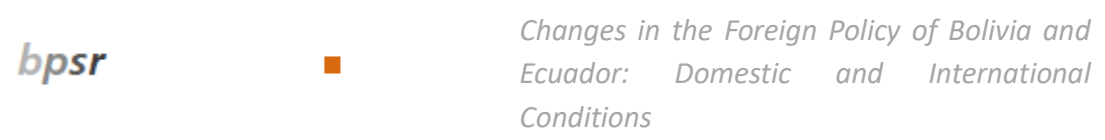

parliamentary majorities, arbitrary aspirations of the Executive, and also interventions in the Judiciary.

Since redemocratization, two convergent patterns of behavior of the Executive can be perceived, which intensified over the years: attempts to centralize power in the hands of the president and attempts to implement economic and state reforms. Both seemed to be complementary in political and economic life in Ecuador: the Executive sought centralization and to increase its prerogatives in order to put its institutional and economic restructuring plan into practice, based on the normative framework of market reforms (something which also happened with the current administration of Lenin Moreno).

For Villa (2004), the period before Rafael Correa was marked by a series of frictional episodes between the Executive and the Legislature, especially in relation to the implementation of neoliberal projects for the reorganization of the economy and the state, often creating what the author in question called a 'decisional blockade', evidencing the lack of minimum consensual agreements among the political class. The situation of the blockade would persist throughout the following administration, which was elected in 2002 after the victory of Colonel Lucio Gutiérrez, one of the leaders of the overthrow of Mahuad. He received the official support of the Confederation of Indigenous Nationalities of Ecuador (CONAIE) and promised a programmatic shift to the left. However, once in office Gutiérrez maintained the programmatic orientation and would be overthrown in 2005 in the middle of massive popular protests. The instability would only calm down after the election of Rafael Correa in the second round of the 2006 presidential election.

In the context of Ecuadorian foreign policy, the principal event since redemocratization was the conflict with Peru, the so-called Cenepa War, fruit of the history of almost two centuries of hostilities between the countries. The armed conflict began in January 1995 in the Alto Cenepa Valley, through which ran the Marañón River, part of the Amazon basin and whose demarcation was contested by Ecuador (SOUZA and SANTOS, 2017). It ended on 17 February 1995, with the signing by the representatives of both countries of a peace treaty in Itamaraty Palace in Brazil. The definitive resolution of the conflict occurred on 26 October 1998 with 
the signing of the 'Presidential Act of Itamaraty' by both countries. The territorial conflict with Peru would mark the foreign policy of the country to the extent that it would be responsible for the development of a 'foreign service extremely specialized in territorial law' (BONILLA and PÁEZ, 2006).

\section{The Correa administration}

From the beginning of his term in office, Correa tied his permanence in power to the need for majoritarian support from Ecuadorian voters. For this reason his government was identified by many as a 'plebiscitarian democracy' (ALTMAN, 2010; CONAGHAN, 2008; DE LA TORRE, 2010; MAYORGA, 2008) since it often resorted to elections and popular consultations. After assuming the presidency Correa won all the electoral disputes he competed in. While minoritarian presidents had ended up being blocked by the Legislature, Correa did not run candidates to the Legislature in his first - and victorious - election campaign, alleging the need to replace the Congress elected in 2006 with the convocation of a future Constituent Assembly. The maneuver was successful, since $82 \%$ of the population consulted in a plebiscite (in 2007) approved its convocation and the popularity obtained by the president for fulfilling the promise guaranteed him the election of $56.2 \%$ of the constituent assembly deputies, with a strong replacement rate of previous deputies (SOUZA, 2013a).

The conclusion of the constituent assembly resulted in important political party realignments, with Correa's party, Alianza PAIS, becoming predominant with almost half the votes (although still without an absolute majority in Congress), while the opposition fragmented, with the loss of relevance of the oldest parties, replaced by organizations which were often merely provincial. Correa achieved not only his permanence in power, but also the implementation of his agenda and thus the maintenance of a large part of his popularity during his mandates. While previous Ecuadorian presidents had carried out the so-called 'policy switch' or electoral fraud (SOUZA, 2007b), promising a center-left government but after being elected implementing a radical shift in the opposite direction, Correa fulfilled a large part of his promises (SOUZA, 2013b).

However, an analysis of the relationship between the Correa administrations and the leftwing movements, parties, and groups shows the 
growing distancing of the government from some of its initial supporters. As Lalander and Ospina Peralta (2012) have shown, both the indigenous groups and classical leftwing groups, such as the Ecuadorian Socialist Party (PSE), supported Correa at the beginning of his mandate. However, this approximation only lasted a little more than a year, until the approval of the Citizen Constitution in 2008: following this both the indigenous organizations and part of the PSE, as well as the main trade union organizations in the country gradually moved into opposition to the government.

While initially there were many similarities, Lalander and Ospina Peralta (2012) argue that over the years the pragmatic differences between the principal indigenous organizations and 'Alianza PAIS' increased, expressed in a series of issues, amongst which the two most important ones were government policies linked to support for mining and different conceptions of the action of social movements and their independence from the government. In relation to the former, it should be noted that the indigenous movements were opposed to the promotion of mining on a large scale, defended by the government as one of the principal forms of financing for the country. Over time, Rafael Correa's administration became ever more enthusiastic about the economic potential of mining and less concerned with its environmental effects, leading to the definitive breach between the government and CONAIE in 2012. The emergence of a new cycle of extractivism was perceived by indigenous organizations as damaging to the environment and contrary to some of the principles of the 2008 Constitution (LALANDER and PERALTA, 2012, p. 121).

\section{Ecuadorian foreign policy}

The period of strong political instability (SOUZA, 2013a, 2013b, 2007a, 2007b) which the country had faced since 1996 meant that many of the country's international actions followed a pattern which became known as 'reactive and inertial' (JARAMILLO, 2007). In addition, the political instability exposed the fragilities of the country to external shocks such as the 1997-99 financial crisis, US foreign policy post-September 11, and the failure of the Doha round negotiations (JARAMILLO, 2007). 
Nevertheless, while the diagnostic of the period points to the low importance of Ecuadorian foreign policy in the 1990s, by tracing the constants in the international insertion of the country during this decade, three central points can be identified: 01. the commercial and strategic connection strongly associated with the United States; 02. the concentration of its international agenda on bilateral relations with Colombia and Peru; 03. the lack of clarity in relation to a Latin American and Andean regional integration project (BONILLA and PÁEZ, 2006; JARAMILLO, 2007; ZEPEDA, 2011; ZEPEDA and EGAS, 2011).

Bilateral relations with the United States, Colombia, and Peru - in this order of decreasing importance - acquired prominence in Ecuadorian foreign policy. The approximation with the first two occurred to a great extent due to commercial relations and with the latter to territorial questions and the Cenepa War. Furthermore, the serious financial crisis faced by the country during the 1990s and the first half of the following decade demanded greater dialogue with the European Union, especially Spain, due to the large Ecuadorian emigration to this country during the two previous decades. In this context, the pattern of bilateral relations with the United States during the 1990s was based to a great extent on economic dependence which, consequently resulted in political alignment (JARAMILLO, 2007). In this context, Bonilla (2008) shows that the country never adopted an openly anti-US posture and its position towards the country could be ambivalent, varying between 'evasion and resistance'.

In this scenario its dependence was configured as follows 01 . flows of fiscal credits from the IMF and the World Bank; 02. the maintenance of these flows demanded, to a certain extent, cooperation to form linkages maintaining the US as the relevant decision making actor within these institutions; 03. this cooperation resulted in joint actions in various areas, such as drug trafficking, terrorism, etc. (JARAMILLO, 2007). Correa's assumption of the presidency imprinted new contours on foreign policy, as indicated by his administration's programmatic documents ${ }^{7}$ (MALAMUD and ROSELL, 2009; ZEPEDA, 2011; ZEPEDA and EGAS, 2011). In these the country's international insertion were strongly associated with South-South cooperation, which would impact not only on the form of the country's relations 
with the United States, but also regional integration projects, both for the Andean region and the whole of South America (AYLLÓN and DOLCETTI-MARCOLINI, 2016; ZEPEDA, 2011).

\section{Regional integration projects}

With the arrival of Correa in the presidency, Ecuadorian foreign policy would assume a 'new Latin Americanism' (JARAMILLO, 2007) the principal components of which are the strengthening of South-South cooperation in Andean, South American, and Caribbean circuits (AYLLÓN and DOLCETTI-MARCOLINI, 2016; BONILLA and PÁEZ, 2006; JARAMILLO, 2007; ZEPEDA, 2011; ZEPEDA and EGAS, 2011).

The movement in relation to integration projects with a focus on the South American, and especially the Andean region, can be observed in the country's support for initiatives such as the Bolivarian Alternative for the Americas (Alba), a bloc proposed and led by Venezuela - with whom the country in general sought to align itself - as an alternative to the neoliberal integration initiatives. Moreover, at the same time that it signaled the possibility of joining Mercosur, it paid close attention to and supported the formation of the Union of South American Nations (UNASUR). Rafael Correa's administration also defended the full integration of Cuba in regional organizations such as the Organization of American States (OAS), but due to the growing divergences within the latter organization, it enthusiastically supported the creation of a substitute regional space that also excluded the United States which resulted in the formation of the Community of Latin American and Caribbean States (CELAC) in 2010 (FREIDENBERG, 2012; MALAMUD and ROSELL, 2009; ZEPEDA, 2011; ZEPEDA and EGAS, 2011).

\section{Extra-regional relations}

In the context of the expansion of its international action, Ecuador was heading in the direction of expanding its economic and political dialogue with countries such as Russia, Iran, Syria, and China (FREIDENBERG, 2012; MALAMUD and ROSELL, 2009; POLGA-HECIMOVICH, 2013). The strategic calculation, which was at the same time 'original and controversial' (MALAMUD and 
ROSELL, 2009), acknowledged that the diversification of commercial relations to a great extent acquired a dual function as it aimed at an 'intelligent and sovereign' insertion. On the one hand, the reduction of dependency on the United States. On the other, the indication of the willingness of the Correa administration to open nontraditional relations, in this case not directly related to geographic proximity, notably those which could represent alternatives to US predominance (MALAMUD and ROSELL, 2009; ZEPEDA and EGAS, 2011).

The country signed its first cooperation agreements with Russia in 2008, including the military sector (FREIDENBERG, 2012; MALAMUD and ROSELL, 2009). The expansion of economic and commercial relations with China gained a new format after it purchased $60 \%$ of Ecuadorian foreign debt. In addition, demonstrations of this disposition could be seen in the 2012 visit of the People's Republic of China's Minister of Trade, who was met by President Correa and his Minister of Foreign Affairs (FREIDENBERG, 2012).

It is also worth noting that in 2007, in the first year of Correa's term, Ecuador decided to rejoin the Organization of the Petroleum Exporting Countries (OPEC). It had been an active member of OPEC from 1973 to 1992, though its membership was suspended between 1992 and 2007, the period which corresponded to the peak of Ecuadorian instability (ORTIZ, 2011). However, in 2020, Lenín Moreno opted to leave OPEC again, claiming there was a need to reduce public expenditure and produce new revenues.

\section{Relations with United States}

For Zepeda (2011), relations with actors from the Global North in the Correa administration increasingly lost space - at least in the official discourse. According to him, Ecuadorian diplomacy sought to distance itself, at least in the political sphere, from its principal commercial partner - the United States (ZEPEDA, 2011, p. 119). It should be noted that this strategy means that for the Ecuador-US relationship for the first time Washington had become a secondary target for the Ecuadorian government, even in commercial terms (JARAMILLO, 2007).

In this way, the renegotiation of the agreements identified as unequal and the maneuvers which aimed to find spaces of action other than traditional 
international financial institutions came to have more space in the agenda. One of the main examples of this new strategy was Ecuador's abandonment of ICSID in 20098. Leaving ICSID was only possible thanks to a series of changes and revisions made in the country after the enactment of the 2008 Constitution, with the effective construction of legislation and institutions related to the theme, culminating, in accordance with Bas Vilizzio (2015), in the creation of the 'Comisión para la Auditoría Integral Ciudadana de los Tratados de Protección Recíproca de Inversiones y del Sistema de Arbitraje Internacional en Materia de Inversiones' (CAITISA) in 2013. Another important foreign policy initiative by Rafael Correa was the support for the development of the 'Banco del Sur' at the end of the 2000s, in partnership with other center-left countries such as Brazil, Venezuela, Argentina, Bolivia, Paraguay, and Uruguay, amongst others. This new initiative, according to Rosales (2013, p. 28), had the aim of allowing the establishment of a new regional financial architecture and gradually replacing international financial institutions with others with greater regional impact.

Foreign policy in this period sought to move away from the project carried out during the decades before Correa, although this signified costs for the traditional commercial strategic alliance with the United States (JARAMILLO, 2007). Even though there is no clarity about the shape of cooperation with Washington, two lines can be identified: a high degree of autonomy in various areas and a 'vigilant distancing' (JARAMILLO, 2007).

In this context, the 2007 decision not to renew the contract for Manta Airbase (a US military base located in Ecuadorian territory) can be perceived as an indication of the reorientation of Ecuador's relationship with the United States, since this occupied a fundamental strategic position in US anti-drug trafficking policy (MALAMUD and ROSELL, 2009; ZEPEDA, 2011; ZEPEDA and EGAS, 2011).

However, any possibility of re-approximation was interrupted in February 2009 through the publication of details of the agreement made by the US government and the Ecuadorian National Police which stipulated that the leaders of the latter were to be chosen by the US which in exchange would make financial

\footnotetext{
${ }^{8}$ In addition to Ecuador and Bolivia, Venezuela (2012) also abandoned ICSID, alleging similar reasons. For more details about the exit of these countries, see Bas Vilizzio (2015).
} 
contributions to improve the police (MALAMUD and ROSELL, 2009; ZEPEDA, $2011)^{9}$.

President Correa stated at the time that the incident represented a serious offense to Ecuadorian sovereignty. With evidence that sensitive information from the National Police had been intercepted by US embassy staff in Quito, the president expelled two members of the US diplomatic mission: the customs attaché Armando Astorga and Max Sullivan, first secretary of the diplomatic legation. The case thus represented the moment of greatest stress in Ecuador-US relations (MALAMUD and ROSELL, 2009; ZEPEDA, 2011). However, a month later the government signaled its intention to maintain a 'fraternal relationship' with the US (MALAMUD and ROSELL, 2009). In response to the closing of the base and the expulsion of its diplomats, the US government chose to transfer all its military apparatus in the country to Colombia, which included at the time ships, aircraft, arms, and espionage devices. Finally, it is worth citing the famous political asylum for the founder of Wikileaks, Julian Assange, in the Ecuadorian embassy in London in August 2012, rescinded in April 2019 by his successor, Lenin Moreno.

In summary, associated with the elements which characterized the international insertion of the country at this moment were: 01 . the strengthening of South-South cooperation which would impact not only on the form of the country's relationship with the United States but also 02. regional integration projects both in the Andean region and South America as a whole (AYLLÓN and DOLCETTIMARCOLINI, 2016; BONILLA and PÁEZ, 2006; FREIDENBERG, 2012; JARAMILLO, 2007; MALAMUD and ROSELL, 2009; ZEPEDA, 2011; ZEPEDA and EGAS, 2011).

In relation to foreign trade and exports in particular, the US remained Ecuador's main partner, and there was a significant increase of exports (mostly oil) during the 2000s, with two moments of decline. The first was in 2009 (due to the diplomatic conflicts between the two countries) and the second in 2014 (when there was a significant fall in the price of oil in the international scenario). Also noteworthy is the increase in exports to China, practically irrelevant at the beginning of the 2000s, but after Correa reached the presidency these began to increase. In relation to imports from China, a significant increase can be observed in

\footnotetext{
${ }^{9}$ It should be noted that the following year President Rafael Correa was the victim of an unsuccessful police mutiny organized by some leaders of the Ecuadorian national police.
} 
the second half of the 2000s, especially after Correa took office. Imports from both countries also declined after 2014 (the same year as the fall in oil prices), practically equaling in the second half of the 2010 s.

Graph 02. Ecuadorian trade flows (1991-2018)

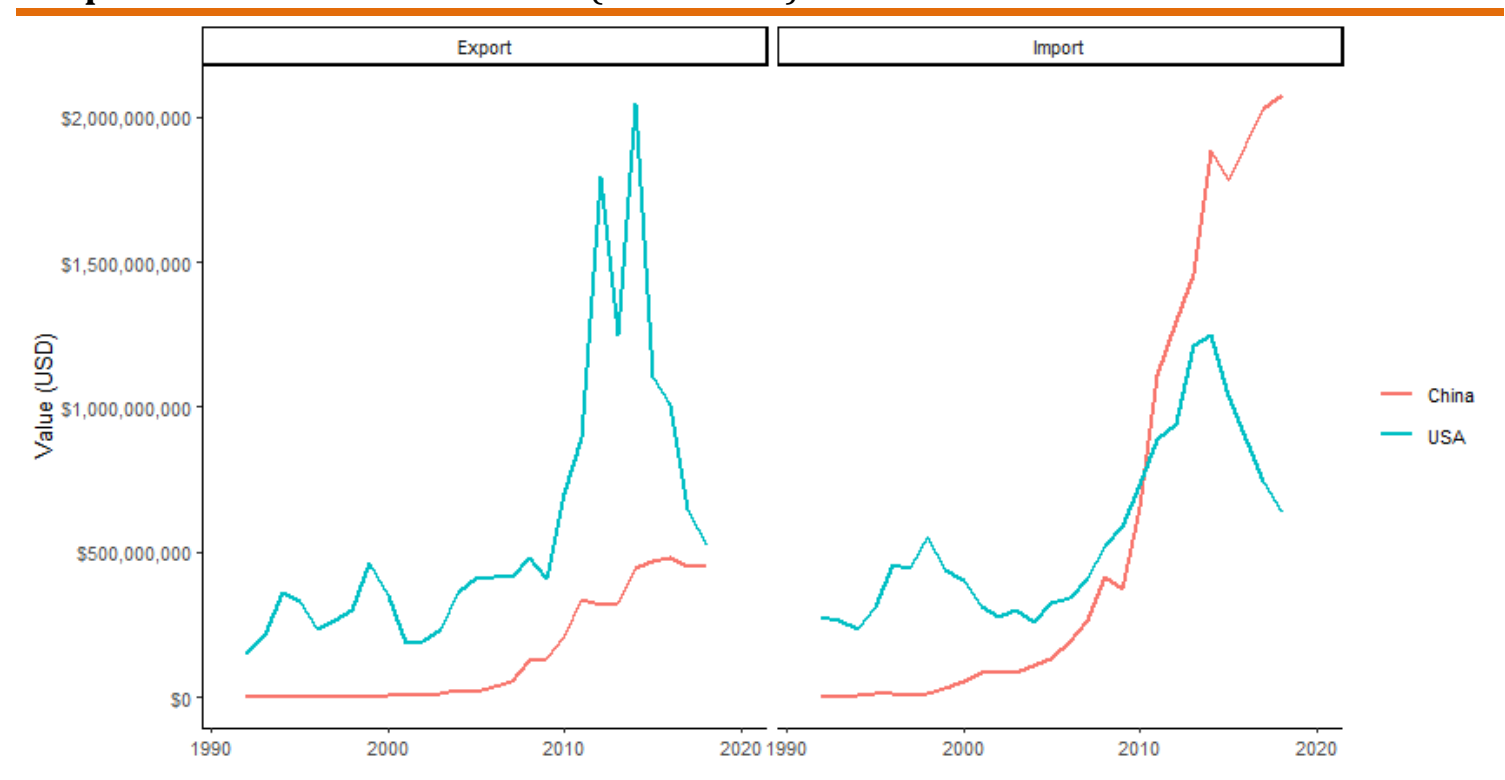

Source: Elaborated by the authors based on UN Comtrade (2020).

This moment also corresponded to the renegotiation of the Ecuadorian foreign debt in new terms and the period of a great rise in oil prices in the international market, leading to a significant increase in the country's foreign reserves until 2014, when, as mentioned above, there was a great downturn in oil prices. Also important here is the great increase in the volume of imports from China, which as stated in the last section of this article became one of Ecuador's main partners in the 2010s, almost drawing in first place with the US.

\section{Final considerations}

In this paper, our main objective was to make a brief comparison of the main political events that occurred in Bolivia and Ecuador in the last 25 years, with a special emphasis on the foreign policy itinerary in both countries, especially in relation to the contemporary period, led in Bolivia by Evo Morales and in Ecuador by Rafael Correa. 
In the article we took into account the interaction between domestic and international factors in both countries, understanding that neither of the two dimensions should be understood as more important. Our hypothesis suggests a reorientation of foreign policy based on the rise to power of center-left presidents (Rafael Correa and Evo Morales), who were successful in forming parties or coalitions which became hegemonic, allowing the diversification of commercial partnerships and the advent of an anti-US tone in the foreign policy field.

Of importance in both countries is political instability and economic crises, especially in the 1990s and the beginning of the 2000s. In this period, both Bolivia and more especially Ecuador went through traumatic overthrows of presidents, interfering to a great extent in the direction of foreign policy in these Andean countries due to the immense political instability, which resulted in a reactive orientation and foreign policy inertia, incapable of great strategic planning. However, despite some wavering, the US remained the main foreign trade partner of both countries in the periods when the center-right was in power. After Evo Morales came to power in Bolivia and Rafael Correa in Ecuador the scenario changed. Both countries sought to expand the number of commercial partners and encouraged south-south integration (with special importance for initiatives in the Latin American sphere), as well as the gradual distancing of US influence and a significant approximation with China.

However, this reorientation was only feasible thanks to the reorganization and stabilization of their respective party systems led by new presidents (SOUZA and SANTOS, 2017), operating as the necessary condition for new internal actors to be able to translate their programmatic preferences into the reorientation of public policies. Nevertheless, although this change (the rise of leftwing governments) originated in the domestic sphere, the electoral victories of Morales and Correa occurred at a moment of the relative distancing from the US which was focused on its priorities in the Middle East and during the expansion of center-left governments in the region, positively influencing both presidents, who gained increased space for maneuvers in the international sphere. We thus believe that greater political stability represents an INUS ${ }^{10}$ condition

${ }^{10}$ Acronym for 'Insufficient but Necessary parts of a condition which is itself Unnecessary but Sufficient'. 
(AMORIM NETO and RODRIGUEZ, 2016; MAHONEY and GOERTZ, 2006), resulting in a greater possibility for a planned foreign policy that is oriented to the mid-term at least and capable of taking better advantage of the expanded limits for the favorable foreign scenario.

Below we have prepared a Venn Diagram which organized the principal changes in the foreign policies of Bolivia and Ecuador, taking into account the interaction between the domestic and international spheres for the three variables analyzed in the article for each country:

Diagram 01. Foreign Policy Changes in Bolivia and Ecuador

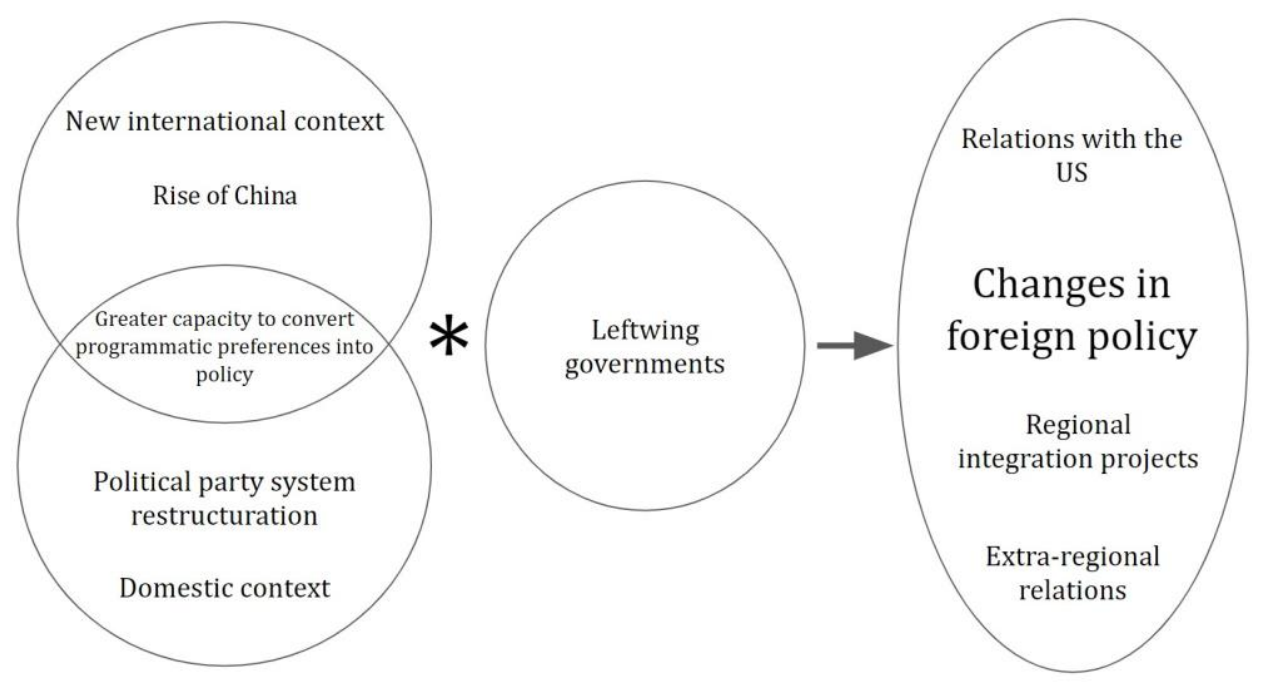

Source: Elaborated by the authors.

As Diagram 01 illustrates, there are two INUS conditions for the change in direction in Bolivia and Ecuador's foreign policies: in the international sphere the greater space for maneuver granted by the relative withdrawal of the US from the region and the intensification of the Chinese presence; and in the domestic sphere the political stability which gave the new governments greater predictability and institutional capacity, guaranteeing a new political party restructuring. Having guaranteed these necessary conditions, it became possible for the new leftwing governments to translate their programmatic preferences into a reorientation of foreign policy, with new themes and priorities of action. 
By way of conclusion, although it is not the object of this article to analyze the post-Morales and Correa scenario in the two countries, the rapid reversal following the presidential successions of many of the changes that had been implemented is significant. Both in Ecuador, following the election in 2017 of Lenin Moreno, from the same party as Correa (Alianza PAÍS), and in Bolivia, after the interim president Jeannine Añez took office following the overthrow of Morales in November 2019 in the middle of protests over suspicions of fraud in the elections of that year, the new period has been marked by a re-approximation with the US, moving away from previous allies such as Venezuela and Cuba, and the progressive abandonment of regional integration spheres such as UNASUR and CELAC. More detailed studies are certainly necessary to make greater affirmations about this new scenario. However, despite a certain recent deterioration in the political stability, both are still relatively stable (above all in comparison with the 1990-2000s scenarios), while external factors are also relatively similar, it thus seems reasonable to expect that the sudden programmatic reorientation of the new administrations will also translate into new external priorities.

Translated by Eoin Portela Submitted on January 25, 2020 Accepted on August 31, 2020

\section{References}

ACOSTA, Alberto (2006), Breve história econômica do Equador. Brasilia: FUNAG/IPRI. 333 pp..

AGUIRRE, Jessica Camille and COOPER, Elizabeth Sonia (2010), Evo Morales, climate change, and the paradoxes of a social-movement presidency. Latin American Perspectives. Vol. 37, № 04, pp. 238-244.

AGUSTÍN, Óscar García (2016), Reconfiguring political alliances and the role of swing states: the strategy of Bolivia and its relations with the BRICS. In: Emerging powers, emerging markets, emerging societies: global responses. Edited by CHRISTENSEN, Steen Fryba and LI, Xing. Basingstoke: Palgrave Macmillan. pp. 185-208.

ALTMAN, David (2010), Plebiscitos, referendos e iniciativas populares en América Latina: ¿mecanismos de control político o políticamente controlados? Perfiles latinoamericanos. Vol. 18, № 35, p. 09-34. 
ALTMAN, David and LALANDER, Rickard (2003), Bolivia's popular participation law: an undemocratic democratisation process? In: Decentralisation and democratic governance: experiences from India, Bolivia and South Africa. Edited by HADENIUS, Axel. Stockholm: Almqvist \& Wiksell International. pp. 63-104.

AMORIM NETO, Octavio and RODRIGUEZ, Júlio César Cossio (2016), 0 novo método histórico-comparativo e seus aportes à ciência política e à administração pública. Revista de Administração Pública. Vol. 50, № 06, pp. 1003-1027.

AYLLÓN, Bruno and DOLCETTI-MARCOLINI, Michele (2016), Revolución ciudadana y refundación constitucional en Ecuador: políticas públicas y cooperación para el Buen Vivir. Estado \& Comunes. Revista de políticas y problemas públicos. Vol. 01, № 02, pp. 33-51.

BAS VILIZZIO, Magdalena (2015), Algunas reflexiones en torno al retiro de Bolivia, Ecuador y Venezuela del CIADI. Densidades. № 07, pp. 51-67.

BIRNS, Larry and SANCHEZ, Alex (2011), From obscurity to center stage: the architectonics of Bolivia's foreign policy. In: Latin American foreign policies: between ideology and pragmatism. Edited by GARDINI, Gian Luca and LAMBERT, Peter. New York: Palgrave Macmillan. pp. 103-118.

BONILLA, Adrián (2008), 25 años de política exterior: Ecuador. Paper. Quito: FLACSO.

BONILLA, Adrián and PÁEZ, Alexei (2006), Estados Unidos y la región andina: distancia y diversidad. Nueva Sociedad. № 206, pp. 126-139.

BRUSLÉ, Laetitia Perrier (2015), La integración continental sudamericana, inscripción espacial y dispositivo discursivo. Apuntes desde Bolivia, el país de contactos. Journal of Latin American Geography. Vol. 14, № 02, pp. 101-127.

CONAGHAN, Catherine M. (2008), Ecuador: Correa's plebiscitary presidency. Journal of Democracy. Vol. 19, № 02, pp. 46-60.

COSTOYA, Manuel Mejido (2011), Politics of trade in post-neoliberal Latin America: the case of Bolivia. Bulletin of Latin American Research. Vol. 30, № 01, pp. 8095.

CUNHA FILHO, Clayton M. (2018a), Dilemmas of contemporary political representation in Bolivia: social movements, party, and state in plurinational times. In: Civil society and political representation in Latin America (2010-2015): towards a divorce between social movements and political parties? Edited by ALBALA, Adrián. New York: Springer. pp. 131-147.

CUNHA FILHO, Clayton M. (2018b), Formação do Estado e horizonte plurinacional na Bolívia. Curitiba: Appris. 373 pp.. 
CUNHA FILHO, Clayton M. (2017), Qualidade democrática na Bolívia de Evo Morales (e além): transformações, avanços e desafios. Teoria \& Pesquisa. Vol. 26, № 02, pp. 30-68.

CUNHA FILHO, Clayton M. (2016), Estrategias de desarrollo e inserción internacional en la Bolivia de Evo Morales. Revista Andina de Estudios Políticos. Vol. VI, № 01, p. 142-162.

CUNHA FILHO, Clayton M. (2015), 'Um país de contatos': a política exterior boliviana entre Haia e a integração regional. Observador On-line. Vol. 10, № 08, p. 01-17.

CUNHA FILHO, Clayton M. (2014), Haia e a consolidação da demanda marítima boliviana como questão de Estado. Boletim OPSA. Vol. 10, № 02, pp. 06-10.

CUNHA FILHO, Clayton M. (2008), 0 ano da virada de Evo Morales? Observador Online. Vol. 03, № 12, pp. 02-17.

CUNHA FILHO, Clayton M. and DELGADO, Ana Carolina (2010), Ideologia e pragmatismo: a política externa de Evo Morales. Tensões Mundiais. Vol. 06, № 10, pp. 287-310.

CUNHA FILHO, Clayton M. and GONÇALVES, Rodrigo Santaella (2010), The national development plan as a political economic strategy in Evo Morales's Bolivia. Latin American Perspectives. Vol. 37, № 04, pp. 177-196.

CUNHA FILHO, Clayton M.; VIANA, João Paulo Saraiva Leão (2010), A Bolívia e os desafios da integração regional: crise de hegemonia, instabilidade e refundação institucional. In: Integração Sul-Americana: desafios e perspectivas. Edited by VIANA, João Paulo Saraiva Leão; VASCONCELLOS, Patrícia Mara Cabral de; MIGUEL, Vinícius Valentin Raduan. Porto Velho: EdUFRO. pp. 224-250.

DE LA TORRE, Carlos (2010), El gobierno de Rafael Correa: posneoliberalismo, confrontación con los movimientos sociales y democracia plebiscitaria. Revista Temas y Debates. № 20, pp. 157-172.

DELGADO, Ana Carolina (2014), Guerreiros do Arco-Íris: os caminhos e descaminhos da descolonização na Bolívia no início do século XXI. Doctoral thesis. Programa de Relações Internacionais. Instituto de Relações Internacionais. Pontifícia Universidade Católica do Rio de Janeiro.

DELGADO, Ana Carolina and CUNHA FILHO, Clayton M. (2016), Bolivia-Brazil: internal dynamics, sovereignty drive and integrationist ideology. In: Foreign policy responses to the rise of Brazil: balancing power in emerging states. Edited by GARDINI, Gian Lucca and ALMEIDA, Maria Hermínia Tavares de. New York: Palgrave Macmillan. pp. 129-144.

ESCOBARI, Amaya Querejazu (2015), Indigeneidad en la política exterior de Bolivia durante el gobierno de Evo Morales (2006-2014). Desafíos. Vol. 27, № 01, pp. 159-184. 
FRANÇA, Carlos Alberto Franco (2015), Integração elétrica Brasil-Bolívia: o encontro no rio Madeira. Brasília: FUNAG. 340 pp..

FREIDENBERG, Flavia (2012), Ecuador 2011: revolución ciudadana, estabilidad presidencial y personalismo político. Revista de Ciencia Politica. Vol. 32, № 01, pp. 129-150.

FUSER, Igor (2014), 0 mito da 'generosidade' no contencioso Brasil-Bolívia do gás natural. Tensões Mundiais. Vol. 10, № 18, pp. 231-254.

GISBERT, Carlos D. Mesa (2006), Presidentes de Bolivia: entre urnas y fusiles. La Paz: Editorial Gisbert. 915 pp..

GUIMARÃES, César; DOMINGUES, José Maurício, and MANEIRO, María (2009), Bolívia: a história sem fim. In: A Bolívia no espelho do futuro. Edited by DOMINGUES, José Maurício; GUIMARÃES, Alice Soares; MOTA, Aurea; SILVA, Fabricio Pereira da. Belo Horizonte; Rio de Janeiro: EDUFMG ; IUPERJ. pp. 1326.

HAARSTAD, Håvard and ANDERSSON, Vibeke (2009), Backlash reconsidered: neoliberalism and popular mobilization in Bolivia. Latin American Politics and Society. Vol. 51, № 04, p. 01-28.

HOFMEISTER, Wilhelm (2004), Bolivia: la construcción de la democracia y la evolución del proceso político. In: Reformas Políticas en América Latina. Edited by HOFMEISTER, Wilhelm. Rio de Janeiro: Fundação Konrad Adenauer. pp. 65101.

JARAMILLO, Grace (2007), Política exterior equatoriana: escenaris divergents de la inserció equatoriana en el món. DCIDOB. № 103, pp. 15-19.

KAUP, Brent Z. (2010), A neoliberal nationalization? The constraints on natural-gasled development in Bolivia. Latin American Perspectives. Vol. 37, № 03, p. 123138.

KOHL, Benjamin H. and FARTHING, Linda (2009), Less than fully satisfactory development outcomes: international financial institutions and social unrest in Bolivia. Latin American Perspectives. Vol. 36, № 03, pp. 59-78.

KOHL, Benjamin H. and FARTHING, Linda C. (2006), Impasse in Bolivia: neoliberal hegemony and popular resistance. London/New York: Zed Books. 256 pp..

LALANDER, Rickard and PERALTA, Pablo Ospina (2012), Movimiento indígena y revolución ciudadana en Ecuador. Cuestiones Políticas. Vol. 28, № 48, pp. 13-50.

LECHÍN, Daniel Agramont (2015), Bolivia mira hacia el sur: el ingreso al Mercosur y la política exterior de Evo Morales. Nueva Sociedad. № 259, p. 15-26. 
LIMA, Maria Regina Soares de (ed)(2008), Desempenho de governos progressistas no Cone Sul: agendas alternativas ao neoliberalismo. Rio de Janeiro: Edições IUPERJ.

MAHONEY, James and GOERTZ, Gary (2006), A tale of two cultures: contrasting quantitative and qualitative research. Political Analysis. Vol. 14, № 03, p. 227249.

MAIRA, Luis (2007), Dilemas internos y espacios internacionales en el gobierno de Evo Morales. Nueva Sociedad. Vol. 209, pp. 66-81.

MALAMUD, Carlos and ROSELL, Carola García-Calvo (2009), La política exterior de Ecuador: entre los intereses presidenciales y la ideología. Boletín Elcano. № 113, pp. 08-29.

MAYORGA, René (2008), Outsiders políticos y neopopulismo: el camino a la democracia plebiscitaria. In: La crisis de la representación democrática en los países andinos. Edited by MAINWARING, Scott; BEJARANO, Ana Maria, and PIZARRO, Eduardo. Bogotá: Editorial Norma. pp. 209-260.

MIRANDA, Carlos (2008), Gas and its importance to the Bolivian economy. In: Unresolved tensions: Bolivia past and present. Edited by CRABTREE, John and WHITEHEAD, Laurence. Pittsburgh: Pittsburgh University Press. pp. 177-193.

MOLINA, George Gray (2001), Exclusion, participation and democratic statebuilding. In: Towards democratic viability: the Bolivian experience. Edited by CRABTREE, John and WHITEHEAD, Laurence. Basingstoke: Palgrave Macmillan. pp. 63-82.

ORTIZ, Luis Francisco Rodriguez (2011), El reingreso de Ecuador en la OPEP: motivaciones y expectativas. Disertación. Previa a la Obtención del Título de Sociologado com Mención em Ciencias Sociales. lítica - Pontifícia Universidad Católica del Ecuador.

PACHANO, Simón (2008), Calidad de la democracia y colapso del sistema de partidos en Ecuador. Paper. FLACSO.

PACHANO, Simón (2006), El peso de lo institucional: auge y caída del modelo boliviano. América Latina Hoy. Vol. 43, pp. 15-30.

PANIZZA, Francisco (2006), La Marea Rosa. Análises de Conjuntura OPSA. Vol. $02, \quad \mathrm{No} \quad 08 . \quad$ Available at $\leq$ http://observatorio.iesp.uerj.br/images/pdf/analise/21_analise s_La_marea_rosa.pdf $\geq$. Accessed on March, 08, 2017.

PÉREZ FLORES, Fidel and KFURI, Regina (2011), Aliança Bolivariana ou a integração como projeto hegemônico. In: Os novos rumos do regionalismo e as alternativas políticas na América do Sul. Edited by VADELL, Javier and CAMPOS, Taiane. Belo Horizonte: PUC Minas. pp. 390-417. 
POLGA-HECIMOVICH, John (2013), Ecuador: estabilidad institucional y la consolidación de poder de Rafael Correa. Revista de Ciencia Política. Vol. 33, № 01, pp. 135-160.

PUTNAM, Robert D. (1988), Diplomacy and domestic politics: the logic of two-level games. International Organization. Vol. 42, № 03, pp. 427-460.

REVETTE, Anna C. (2016), This time it's different: lithium extraction, cultural politics and development in Bolivia. Third World Quarterly. Vol. 38, № 01, pp. 149-168.

ROCHLIN, James (2007), Latin America's left turn and the new strategic landscape: the case of Bolivia. Third World Quarterly. Vol. 28, № 07, pp. 1327-1342.

ROJAS, Máximo Quitral (2014), La política exterior de Evo Morales. Revista Latinoamericana de Desarrollo Económico. № 21, pp. 175-191.

ROSALES, Antulio (2013), The Banco del Sur and the return to development. Latin American Perspectives. Vol. 40, № 05, pp. 27-43.

SILVA, Fabrício Pereira da (2014), Quinze anos da onda rosa latino-americana: balanço e perspectivas. Observador On-line. Vol. 09, № 12, pp. 01-28.

SOUZA, André Luiz Coelho Farias de (2013a), 0 papel da sociedade e das instituições na definição das crises políticas e quedas de presidentes na América Latina. Monções: Revista de Relações Internacionais da UFGD. Vol. 02, № 03, pp. 227260.

SOUZA, André Luiz Coelho Farias de (2013b), Por que caem os presidentes? Contestação e permanência na América Latina. Doctoral thesis. Programa de Pós-Graduação em Ciência Política. IESP. Universidade Estadual do Rio de Janeiro.

SOUZA, André Luiz Coelho Farias de (2007a), Instabilidade presidencial e a polarização entre os atores no Equador. Observador On-line. Vol. 02, № 11, pp. 01-22.

SOUZA, André Luiz Coelho Farias de (2007b), Reflexões sobre a crise política do Equador: governabilidade e atuação do Executivo perante os conflitos entre os poderes, as pressões internacionais e os movimentos sociais. Master's dissertation. Programa de Pós-Graduação em Ciência Política. Universidade Federal do Rio de Janeiro.

SOUZA, André Luiz Coelho Farias de, and SANTOS, Vinicius (2017), Política externa e partidos políticos no Equador em três tempos: redemocratização, crise e realinhamento. Conexão Política. Vol. 06, № 01, pp. 71-94. 
STRÖBELE-GREGOR, Juliana (2013), El proyecto estatal del litio en Bolivia: expectativas, desafíos y dilemas. Nueva Sociedad. № 244, pp. 75-83.

VALLE, Valeria Marina and HOLMES, Héctor Cueto (2013), Bolivia's energy and mineral resources trade and investments with China: potential socioeconomic and environmental effects of Lithium extraction. Latin American Policy. Vol. 04, № 01, pp. 93-122.

VILLA, Rafael (2004), O sistema político equatoriano: continuidades da velha política através da moderna. In: Os países da Comunidade Andina. Edited by ARAÚJO, Heloisa Vilhena de. Brasília: FUNAG/IPRI. pp. 633-677.

ZEPEDA, Beatriz (2011), La política exterior durante el gobierno de Rafael Correa: un balance. Anuario: Seguridad Regional en América Latina y el Caribe. № 01, pp. 114-126.

ZEPEDA, Beatriz and EGAS, María (2011), La política exterior de la revolución ciudadana: opinión y actitudes públicas. Revista Mexicana de Política Exterior. Vol. 93, pp. 95-134. 